\title{
Effect of captopril or verapamil on intracellular sodium in cultured vascular smooth muscle cells ${ }^{1}$
}

QI Jian Hua, Lu ZHANG*, Jun WANG*, Min LU, Xin Ming WANG, Zheng Jun JIN*

Shanghai Institute of Cell Biology, Chinese Academy of Sciences, Shanghai 200031, China.

* Department of Pharmacology, Shanghai Second Medical University, Shanghai 200025, China.

\section{ABSTRACT}

The effects of captopril (Cap) and verapamil (Ver) alone and in combination on intracellular $\mathrm{Na}^{+}$concentration $\left(\left[\mathrm{Na}^{+}\right]_{\mathrm{i}}\right)$ in cultured aortic smooth muscle cells (ASMC) of rabbits was evaluated by a direct measurement of $\left[\mathrm{Na}^{+}\right]_{\mathrm{i}}$ with fluorescent dye sodium-binding benzofuran isophthalate (SBFI) combined with digital image. $\left[\mathrm{Na}^{+}\right]_{\mathrm{i}}$ in resting cells was found to be $11.9 \pm 0.7 \mathrm{mmol} / \mathrm{L}$. Angiotensin II (Ang-II, 0.1-10 $\mu \mathrm{mol} / \mathrm{L}$ ) induced an increase of $[\mathrm{Na}+]_{\mathrm{i}}$ in concentration-dependent manner. Ver (0.1$10 \mu \mathrm{mol} / \mathrm{L})$ inhibited Ang-II $(1 \mu \mathrm{mol} / \mathrm{L})$-induced increase in $\left[\mathrm{Na}^{+}\right]_{\mathrm{i}}$, while Cap enhanced Ang-II-induced increase in $\left[\mathrm{Na}^{+}\right]_{\mathrm{i}}$ at $10 \mu \mathrm{mol} / \mathrm{L}$ but not at $0.1-1 \mu \mathrm{mol} / \mathrm{L}$. Ver (0.1-1 $\mu \mathrm{mol} / \mathrm{L})$ abolished enhancement of Ang-II-induced increase in $\left[\mathrm{Na}^{+}\right]_{i}$ by Cap. Thus, the inhibition of Capenhanced $\left[\mathrm{Na}^{+}\right]_{\mathrm{i}}$ by Ver may provide a new hypothesis for the underlying molecular mechanism of synergistic effect of the combination of $\mathrm{Ca}^{2+}$ antagonists and angiotensinconverting enzyme inhibitors in controlling blood pressure.

Key words: Cultured aortic smooth muscle cells, angiotensin II, captopril, verapamil, sodiumbinding benzofuran isophthalate. 
Captopril or verapamil on $\left[\mathrm{Na}^{+}\right]_{\mathrm{i}}$ in vascular smooth muscle cells

\section{INTRODUCTION}

Vascular smooth muscle cells possess a number of $\mathrm{Na}^{+}$transport systems, namely $\mathrm{Na}^{+}$channels, $\mathrm{Na}^{+}-\mathrm{Ca}^{2+}, \mathrm{Na}^{+}-\mathrm{H}^{+}$exchange, and $\mathrm{Na}^{+}-\mathrm{K}^{+}-2 \mathrm{C} 1^{-}$co-transport[1] Hypothesized roles for these systems include regulation of vascular tone, cell volume and cell proliferation. In both experimental and human hypertension aberrations in smooth muscle cell, univalent ion transport system play an important role in the pathogenesis and maintenance of hypertension[2].

Angiotensin-converting enzyme (ACE) inhibitors and $\mathrm{Ca}^{2+}$ antagonists are widely used for the treatment of hypertension. The combination of both drugs produces a larger hypotensive effect than either drug given alone. However, the mechanisms of this synergistic effect is not well known. The effects of both drugs on $\mathrm{Ca}^{2+}$ fluxes mediated by agonists in vascular smooth muscle cells, which are associated with $\mathrm{Na}^{+}$transport[3] have been studied[4, 5]. But there is scant information as to the the effects of both drugs on $\mathrm{Na}^{+}$regulation.

The purpose of the present study was to evaluate the effect of ACE inhibitor captopril (Cap) and $\mathrm{Ca}^{2+}$ antagonist verapamil (Ver) alone and in combination on angiotensin (Ang-II)-induced changes in intracellular $\mathrm{Na}^{+}\left(\left[\mathrm{Na}^{+}\right]_{\mathrm{i}}\right)$ in aortic smooth muscle cells (ASMC).

\section{MATERIALS AND METHODS}

Sodium-binding benzofuran isophthalate (SBFI)/acetoxymethyl ester(AM) and SBFI was from Sigma. Ang-II was from Sigma. Cap was obtained from Chang Zhou Pharmaceutical Factory, Ver from Shanghai Tian-Ping Pharmaceutical Factory. Mouse anti-human actin and sheep anti-mouse IgG/FITC were purchased from Sino-American Biotechnolgy Co. Medium-199 was from Nissui. Pluronic F-127 and $\mathrm{Me}_{2} \mathrm{SO}$ were purchased from Sigma.

\section{Cell culture}

Passages 9-11 ASMC derived from thoracic aortae of rabbits were cultured as described previously[4]. Immunocytochemical characterization of ASMC was performed using monoclonal antibodies mouse anti-human actin against smooth muscle-specific $a$-actin[6]. Cultured ASMC showed positive staining for $a$-actin with a fluorescence marker sheep anti-mouse IgG/FITC. For the experiments, the cells were grown on thin glass coverslips at a density of (1-5) $\times 10^{5} / \mathrm{ml} .2 \mathrm{~d}$ later, the medium was aspirated and the cells were made quiescent by incubation in Medium-199 containing $0.1 \%$ bovine serum albumin and indicated concentration of Cap and Ver for $48 \mathrm{~h}$ before the studies. $\left[\mathrm{Na}^{+}\right]_{\mathrm{i}}$ change was assessed 6-7 $\mathrm{h}$ after the exposure to Ang-II.

\section{Fluorescent dye loading}

Cell-grown cover slips were rinsed twice with HEPES-buffered solution (HBS) (mmol/L: $\mathrm{NaCl}$ $1, \mathrm{KCl} 5.4 \mathrm{CaCl}_{2} 1.2, \mathrm{MgCl}_{2} 1.2$, HEPES 10 , glucose 5) and loaded for $2 \mathrm{~h}$ at $37{ }^{\circ} \mathrm{C}$ in same $\mathrm{HBS}$ containing $5 \mu \mathrm{mol} / \mathrm{L}$ SBFI/AM dispersed with $0.2 \%$ Pluronic F-127, a nonionic surfactant. After loading, the cells on cover slips were superfused for $10 \mathrm{~min}$ twice with HBS, and then transferred to a tissue chamber mounted on a microscope stage.

\section{Digital imaging methods and image analysis}

SBFI fluorescence (500 $\mathrm{nm}$ emission excited by $340 \mathrm{~nm}$ illumination) from the cells was imaged 


\section{Qi JH et al.}

using a Nikon UV-Fluor objective. The fluoresent images were recorded by photograph (Fig 1). By means of digital image methods as well as PC Vison Plus Frame Grabber (Imaging Technology Inc.,USA), Panasonic color CCTV camera (Matsushita Communication Industrial, Japan) and software (supported by Department of Computer to Medicine, Shanghai Second Medical University), the grey values of image of SBFI-loaded cells were obtained and converted to $\left[\mathrm{Na}^{+}\right]_{\mathrm{i}}$ on calibration curve.
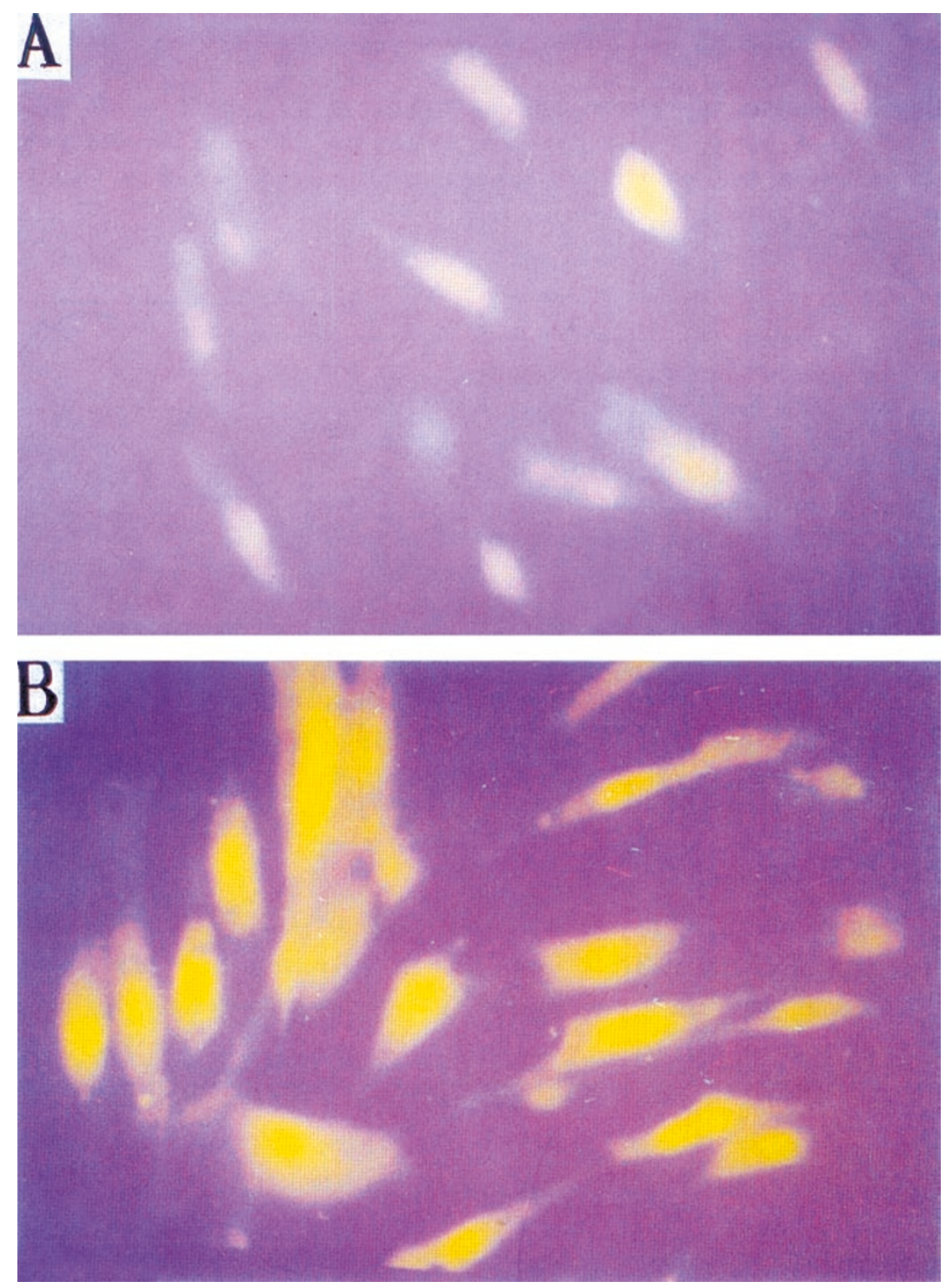

Fig 1. SBFI-loaded rabbit aortic smooth muscle cell fluorescence images after digital image process A: resting cells. B: activated cells $\times 400$. 
Captopril or verapamil on $\left[\mathrm{Na}^{+}\right]_{\mathrm{i}}$ in vascular smooth muscle cells

\section{Calibration of $\left[\mathrm{Na}^{+}\right]_{i}$}

SBFI was calibrated within the cell (in situ calibration) by superfusion of the SBFI-loaded cells with solution containing various $\mathrm{Na}^{+}$concentrations[1]. In the present work, calibration of the excitation in terms of $\left[\mathrm{Na}^{+}\right]_{\mathrm{i}}$ was accomplished in vitro by the application of SBFI with solutions in which the $\mathrm{Na}^{+}$concentration varied from 0 to $20 \mathrm{mmol} / \mathrm{L}$ (Fig 2). $\mathrm{Na}^{+}$calibration solutions were made from appropriate mixtures of $\mathrm{Na}^{+}$and $\mathrm{K}^{+}$solutions $\left(\mathrm{Na}^{+}+\mathrm{K}^{+}=135, \mathrm{CaCl}_{2} 1.2, \mathrm{MgCl}_{2}\right.$ 1.2 , Hepes 10, glucose $5 \mathrm{mmol} / \mathrm{L}$ ).

\section{Statistics}

Data are represented as $\bar{x} \pm \mathrm{s}$ of 40 cells of 4 rabbits, 10 cells/rabbit (as one group). Unpaired $t$-test was used to test the significance of the data. When the differences between group means were evaluated by analysis of multiple variance, it was found to be statistically not significant.

Fig 2. SBFI fluorescence in calibration solution. $1 \mathrm{ml}$ calibration solutions with $\mathrm{Na}^{+}+\mathrm{K}^{+}$ $=135, \mathrm{CaC}_{2} 1.2, \mathrm{MgC1}_{2} 1.2$, Hepes 10 , glucose $5 \mathrm{mmol} / \mathrm{L}$ at $0,2.5,5,7.5,10,15$, $20 \mathrm{mmol} / \mathrm{L} \mathrm{Na}^{+}$were incubated with $5 \mu \mathrm{mol} / \mathrm{L}$ SBFI for $2 \mathrm{~h}$ at $37{ }^{\circ} \mathrm{C}$; Excitation was at $340 \mathrm{~nm}$.

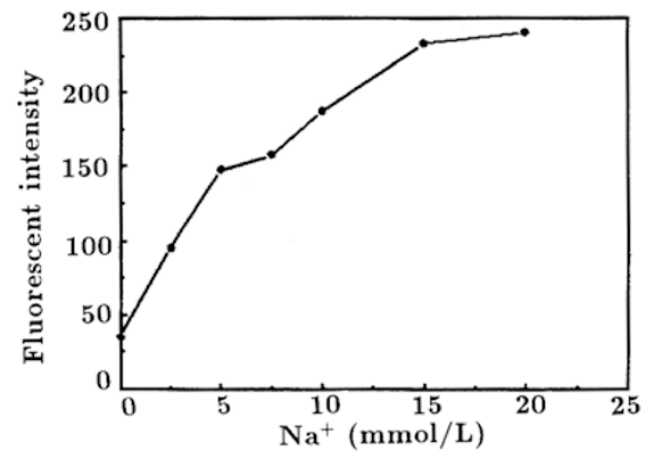

\section{RESULTS}

Ang-II-induced changes in $\left[\mathrm{Na}^{+}\right]_{i}$

$\left[\mathrm{Na}^{+}\right]_{\mathrm{i}}$ level in resting cells (growth arrest for $48 \mathrm{~h}$ in Medium-199 containing 0.1 $\%$ bovine serum albumin at $37{ }^{\circ} \mathrm{C}$ ) was $11.9 \pm 0.7 \mathrm{mmol} / \mathrm{L}$. When resting cells were exposed to Ang-II for $7 \mathrm{~h}$, a concentration-dependent increase in $\left[\mathrm{Na}^{+}\right]_{\mathrm{i}}$ was seen. $\left[\mathrm{Na}^{+}\right]_{\mathrm{i}}$ produced by Ang-II at $0.1,1,10 \mu \mathrm{mol} / \mathrm{L}$ was $12.1 \pm 0.4,12.3 \pm 0.6$, and 12.4 $\pm 0.5 \mathrm{mmol} / \mathrm{L}$, respectively. The maximal amplitude of the increase in $\left[\mathrm{Na}^{+}\right]_{\mathrm{i}}$ was $0.5 \mathrm{mmol} / \mathrm{L}$.

\section{Effect of Vet and Cap on Ang-II-induced changes in $\left[\mathrm{Na}^{+}\right]_{i}$}

The experimental protocol (growth arrest for $48 \mathrm{~h}$ in Medium-199 containing 0.1 $\%$ bovine serum albumin supplemented with the indicated concentration of Ver or Cap at $37{ }^{\circ} \mathrm{C}$ ) was used to determine whether Ver or Cap could alter Ang-II-induced increase in $\left[\mathrm{Na}^{+}\right]_{\mathrm{i}}$. Ver at $0.1,1,10 \mu \mathrm{mol} / \mathrm{L}$ significantly inhibited Ang-II-induced increase in $\left[\mathrm{Na}^{+}\right]_{\mathrm{i}}$ (Tab 1). Cap had little effect on response to Ang-II at 0.1 and $1 \mu \mathrm{mol} / \mathrm{L}$, but enhanced Ang-II-induced increase of $\left[\mathrm{Na}^{+}\right]_{\mathrm{i}}$ at $10 \mu \mathrm{mol} / \mathrm{L}$ (Tab 1). 
Qi JH et al.

However, in the presence of Ver at 0.1 or $1 \mu \mathrm{mol} / \mathrm{L}$, the enhancement of Ang-IIinduced increase in $\left[\mathrm{Na}^{+}\right]_{\mathrm{i}}$ by Cap was abolished (Fig 3).

Tab 1. Effects of captopril and verapamil on angiotensin II $(1 \mu \mathrm{mol} / \mathrm{L})$-induced $\left[\mathrm{Na}^{+}\right]_{\mathrm{i}}$ increase in rabbit vascular smooth muscle cells.

\begin{tabular}{cllc}
\hline $\begin{array}{c}\text { Drug/ } \\
\mathrm{mol} / \mathrm{L}\end{array}$ & $\begin{array}{c}\text { Angiotensin II } \\
{\left[\mathrm{Na}^{+}\right]_{\mathrm{i}} \mathrm{mmol} / \mathrm{L}}\end{array}$ & $\begin{array}{c}\text { Cell } \\
\text { number }\end{array}$ \\
\hline Control & 0 & $12.3 \pm 0.6$ & 40 \\
& $10^{-7}$ & $12.4 \pm 0.5^{*}$ & 40 \\
Captopril & $10^{-6}$ & $12.5 \pm 0.7^{*}$ & 40 \\
& $10^{-5}$ & $12.7 \pm 0.6^{* * *}$ & 40 \\
& $10^{-7}$ & $12.0 \pm 0.5^{* * *}$ & 40 \\
Verapamil & $10^{-6}$ & $12.0 \pm 0.4^{* * *}$ & 40 \\
& $10^{-5}$ & $12.0 \pm 0.4^{* * *}$ & 40 \\
\hline
\end{tabular}

$\bar{x} \pm \mathrm{s}$ of 40 cells from 4 rabbits, 10 cells/rabbit, $* \mathrm{P}>0.05, * * * \mathrm{P}<0.01$ vs Control.

Fig 3. The effect of verapamil (Ver) on the enhancement of angiotensin II (Ang-II, 1 $\mu \mathrm{mol} / \mathrm{L})$-induced increase in $\left[\mathrm{Na}^{+}\right]_{\mathrm{i}}$ by captopril (Cap, $10 \mu \mathrm{mol} / \mathrm{L})$ in rabbit aortic smooth muscle cells. $\bar{x} \pm \mathrm{s}, \mathrm{n}=40$ cells of 4 rabbits, 10 cells/rabbit. $* * \mathrm{P}<0.05$, *** $\mathrm{P}<0.01$ vs control. A: Cap + Ang-II.

B: Ver $(0.1 \mu \mathrm{mol} / \mathrm{L})+$ Cap + Ang-II.

C: Ver $(1 \mu \mathrm{mol} / \mathrm{L})+$ Cap + Ang-II.

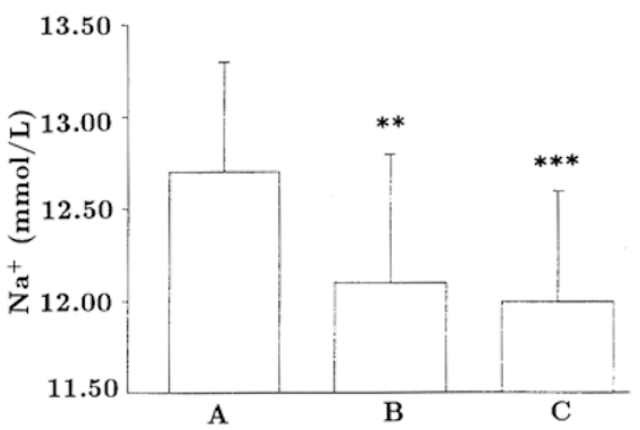

\section{DISCUSSION}

In the present study, $\left[\mathrm{Na}^{+}\right]_{\mathrm{i}}$ was measured with SBFI, monitored by digital imaging fluorescent microscope at a single-cell level and estimated with in vitro calibration protocol. The mean basal $\left[\mathrm{Na}^{+}\right]_{\mathrm{i}}$ determined in ASMC was $11.9 \mathrm{mmol} / \mathrm{L}$. This value is closed to $13 \mathrm{mmol} / \mathrm{L}$ reported by Okada et al[3] which was measured in cuvette for SBFI-loaded rat aorta smooth muscle cells. When the resting cells were exposed to Ang-II for $7 \mathrm{~h}$, a concentration-dependent increase in $\left[\mathrm{Na}^{+}\right]_{\mathrm{i}}$ was seen. In the presence of Ver $(0.1$ to $10 \mu \mathrm{mol} / \mathrm{L})$, this increase in $\left[\mathrm{Na}^{+}\right]_{i}$ was prevented. Clinical data showed that oral application of Ver and ditiazem caused a decrease in $\left[\mathrm{Na}^{+}\right]_{\mathrm{i}}$ in the leukocyte and erythrocyte of hypertensive patients[7, 8]. Our results support the clinical observation, thereby suggesting that a blockade of $\mathrm{Ca}^{2+}$ channel, second to the inhibition of $\mathrm{Ca}^{2+}$-dependent rise in $\left[\mathrm{Na}^{+}\right]_{\mathrm{i}}[1]$, may play a part in hypotensive effect of $\mathrm{Ca}^{2+}$ antagonists. 
Captopril or verapamil on $\left[\mathrm{Na}^{+}\right]_{\mathrm{i}}$ in vascular smooth muscle cells

We also found that Cap enhanced Ang-II-induced increase in $\left[\mathrm{Na}^{+}\right]_{\mathrm{i}}$ at $10 \mu \mathrm{mol} / \mathrm{L}$ but not at 0.1-1 $\mu \mathrm{mol} / \mathrm{L}$. Accetto et al[9] demonstrated that Cap produced inhibition of $\mathrm{K}^{+}$-induced relaxation of rat tail artery. In the study of Unger et al[10], a significant initial pressor effect was observed when Cap was delivered into the lateral cerebral ventricles of stroke-prone spontaneously hypertensive or Wistar-Kyoto control rats. Therefore, these findings suggested that an increase in $\left[\mathrm{Na}^{+}\right]_{\mathrm{i}}$ produced by Cap could contribute toward the increased arterial tone and blood pressure.

Is the enhanced effect of Cap on Ang-II-induced increase in $\left[\mathrm{Na}^{+}\right]_{\mathrm{i}}$ relevant to the clinical use of the drug? Cap peak plasma levels of 0.8 to $1.8 \mu \mathrm{g} / \mathrm{ml}$ were measured after oral administration of approximately 5 to $10 \mu \mathrm{mol} / \mathrm{L}$ Cap[11]. Cap concentration required for the enhancement of Ang-II-induced increase of $\left[\mathrm{Na}^{+}\right]_{\mathrm{i}}$ in the present work $(10 \mu \mathrm{mol} / \mathrm{L})$ was still in the therapeutic range. Thus, an increase in $\left[\mathrm{Na}^{+}\right]_{\mathrm{i}}$ may lead to the limitation of hypotensive effect of the drug. As Cap concentration $\left(\mathrm{IC}_{50}\right)$ required to block angiotensin I conversion was $0.02 \mu \mathrm{mol} / \mathrm{L}[9]$, while Cap 0.1 and $1 \mu \mathrm{mol} / \mathrm{L}$ in the present work did not affect Ang-II-induced increase in $\left[\mathrm{Na}^{+}\right]_{\mathrm{i}}$, low dose of Cap may be reasonable for the clinical use. Interestingly, in the presence of Ver, the enhanced Ang II-induced increase of $\left[\mathrm{Na}^{+}\right]_{\mathrm{i}}$ by Cap was abolished. Perhaps, this can explain partially the clinical findings of a synergistic effect of the combination of $\mathrm{Ca}^{2+}$ antagonists and ACE inhibitors in controlling blood pressure.

In summary, this study demonstrated that Ver inhibited and Cap $(10 \mu \mathrm{mol} / \mathrm{L}$, but not 0.1 or $1 \mu \mathrm{mol} / \mathrm{L}$ ) enhanced Ang-II-induced increase in $\left[\mathrm{Na}^{+}\right]_{\mathrm{i}}$ and that the combination of both drugs could abolish increase in $\left[\mathrm{Na}^{+}\right]_{\mathrm{i}}$ induced by Cap. Therefore, these results may provide a new hypothesis for the underlying molecular mechanism of synergistic effect of the combination of $\mathrm{Ca}^{2+}$ antagonists and angiotensin-converting enzyme inhibitors in controlling blood pressure.

\section{REFERENCES}

[1] Borin ML, Goldman WF, Blaustein MP. Intracellular free $\mathrm{Na}^{+}$in resting and activated A7r5 vascular smooth muscle cells. Am J Physiol 1993; 33:C1513-24.

[2] Orlov SN, Resink TJ, Bernhardt J, Buhler FR. $\mathrm{Na}^{+}-\mathrm{K}^{+}$pump and $\mathrm{Na}^{+}-\mathrm{K}^{+}$co-transport in cultured vascular smooth muscle cells from spontaneously hypertensive and normotensive rats: baselin activity and regulation. J Hypertens 1992; 10:733-40.

[3] Okada K, Ishikawa S, Saito T. Enhancement of intracellular sodium by vasopressin in spontaneously hypertensive rats. Hypertension 1993; 22:300-5.

[4] Qi JH, Zhang L, Wang J, Wei PJ, Gu PK, Jin ZJ et al. Effects of captopril and enalapril on intracellular $\mathrm{Ca}^{2+}$ in vascular smooth muscle cells. Acta Pharmacol Sin 1995; 17:142-45 (in Chinese).

[5] Zhu Z, Tepel M, Neusser M, Mehring N, Zidek W. Effect of captopril on vasoconstriction and $\mathrm{Ca}^{2+}$ fluxes in aortic smooth muscle. Hypertension 1993; 22:806-11.

[6] Bendhack LM, Sharma RV, Bhalla RC. Altered signal transduction in vascular smooth musclecells of spontaneously hypertensive rats. Hypertension 1992; 19(Suppl II):II-42-II-48.

[7] Poston L, Gray HH, Crowther A et al. Cellular sodium concentration and vasoconstrictor state in hypertension. J Cardiovasc Pharmacol 1984; 6:s16-s20. 


\section{Qi JH et al.}

[8] Khalil-Manesh F, Venkataraman K, Samant DR, Gadgil UG. Effects of ditiazem on cationtransport across erythrocyte membranes of hypertensive humans. Hypertension 1987; 9:18-23.

[9] Accetto R, Rinaldi G, Weder AB. Captopril inhibitor ouabain -sensitive $\mathrm{Na}^{+} / \mathrm{K}^{+}$-ATPase. Clin Physiol Biochem 1989; 7:101-8.

[10] Unger T, Kaufmann-Buhler I, Scholkens B, Ganten D. Brain converting enzyme inhibition: a possible mechanism for the antihypertensive rats. Eur J Pharmacol 1981; 70:467-78.

[11] Duchin KL, Singhvi SM, Willard DA. Captopril kinetics. Clin Pharmacol Ther 1982; 31:452-9.

Received 1-12-1995. Revised 23-5-1996. Accepted 24-5-1996. 